\title{
THE INFLUENCE OF CYNICISM ON MOOD EFFECT IN ADVERTISING
}

\author{
DOI: 10.17261/Pressacademia.2020.1224 \\ JMML- V.7-ISS.2-2020(1)-p.66-71
}

\section{Chih-Huang Lin}

Feng Chia University, College of Business, 100 Wenhwa Rd, Seatwen, Taichung 40724, Taiwan ROC. linchihh@fcu.edu.tw, ORCID: 0000-0002-4813-154X

Date Received: February 26, 2020

Date Accepted: May 12, 2020

To cite this document

Lin, C.H., (2020). The influence of cynicism on mood effect in advertising. Journal of Management, Marketing and Logistics (JMML), V.7(2), p.6671.

Permanent link to this document: http://doi.org/10.17261/Pressacademia.2020.1224

Copyright: Published by PressAcademia and limited licensed re-use rights only.

\section{ABSTRACT}

Purpose- The present study introduces the construct of cynicism in consumer behaviour domain. Specifically, this article investigates how cynical individuals behave differently from non-cynical individuals in marketplace.

Methodology- In other words, this study examines the impact of cynicism on the mood effect in relation to attitude toward advertising. The experiment examines the interactions between cynicism and mood states.

Findings- Data from the experiment shows that cynical consumers do have different ads information processing strategies from non-cynical consumers. Moreover, happy cynical consumers exhibit most favorable attitude toward the ads.

Conclusion- Cynicism is characterized by a perception of a pervasive, systematic lack of trust or integrity in human nature, which could be seen as a stable individual difference or dispositional variable. Empirical data suggests that cynical consumers do have different ads information processing strategies from non-cynical consumers. Furthermore, happy cynical consumers exhibit most favorable attitude toward the ads.

Keywords: Cynicism, mood, attitude.

JEL Codes: M30, M31, M37

\section{INTRODUCTION}

Cynicism research has emerged as an important area of investigation in consumer behavior, organizational behavior, politics, and social issues. The consensus emerging from these studies suggest that cynicism can influence consumers in evaluating products and advertising information (Kanter \& Wortzel, 1985; Kanter, 1989; Mangleburg \& Bristol, 1998; Obermiller \& Spangerberg, 1998; Obermiller et al., 2005; Tan \& Tan, 2007), employee behavior in organization (Bateman et al., 1992; Guastello et al., 1992; Anderson \& Bateman, 1997; Wanous et al., 2000; Turner \& Valentine, 2001; Stanley et al., 2005; Naus et al., 2007), citizens in political behavior (Agger et al, 1961; Schenck-Hamlin et al., 2000; ; Pinkleton et al., 2002; Vreese, 2005; Yoon et al., 2005; Kaid, et al.,2007), people's attitude toward ethics and morality (Turner \& Valentine, 2001), and citizenship opinions toward social issues.

Research indicates that 54 percent of Europeans believe "most TV advertising is devious," and 42 percent of British consumers lack trust in brands today (Lidstone, 2005). Moreover, 43 percent of the American working population fit the profile of the cynic (Kanter \& Wortzel,1985; Kanter \& Mirvis, 1989). Cynicism has become a fundamental dimension of decision-making in consumer behaviour (Turner \& Valentine, 2001). That is, the total media environment, films, and music included, cynical workplace, and an uncertain economy have produced a cynical decade (Kanter, 1989). Marketers, advertisers and especially scholars have apparently addressed focus on cynicism in consumer behavior.

Yet studies have produced mixed findings as to how consumer cynicism is used in marketing considerations, especially in advertising information processing. For example, Obermiller et al. (2005) reported that more skeptical consumers like advertising less, rely on it less, attend to it less, and respond more positively to emotional appeals than to informational appeals. Moreover, 
some studies have shown that consumer cynicism could be seen as an antecedent of skepticism, and is positively correlated with skepticism in processing advertising information. However, other studies have demonstrated that consumer cynicism is negative correlated with optimism, life satisfaction, and self-esteem. Furthermore, the relationship between consumer cynicism and the advertisement information-processing is not clearly understood.

A number of consumer studies have investigated how mood states influence consumers. Prior research has examined how mood states have impact on recall (Lee \& Sternthal, 1999), purchase intentions, advertisements (Swinyard, 1993), and the amount of cognitive elaboration consumers engage in (Barone, Maniard, \& Romeo, 2000). Specifically, in the context of information processing, many studies suggest that happy mood result in heuristic processing, whereas sad mood result in more effortful processing (Bagozzi, Gopinath, \& Nyer, 1999). However, consumer research regarding cynicism on mood effects has not been explored.

The present research suggests that such mixed research findings and unknown relationships can be more easily understood and integrated based on the premise that consumer cynicism is an enduring individual dispositional variable. Which means this study takes cynicism as seeing selfishness and fakery at the core of human nature. Cynical individuals regard distrust of human nature the central feature of their overall view of life. Furthermore, cynicism is not simply a work attitude, nor the attitude toward some special objects; it is an outlook on life as a whole. In other words, like other personality traits, cynicism in general could be viewed as a dispositional variable.

\section{LITERATURE REVIEW}

Cynicism in consumption -Kanter and Mirvis (1989) reported that 43 percent of Americans are cynical. Understanding the behavioral pattern of these people is the priority task of every company. How to make the appropriate marketing, advertising, promotion campaigns and target the right segmentations usually means a lot. Taking cynicism as a marketing consideration becomes more and more important to companies. Research has presented that cynical individuals and non-cynical individuals have differences in persuasability.

The focus of studying cynicism toward the consumers, consumption, market and marketing strategy is getting more and more attention. The term "Consumer cynicism" concerns in particular the cynicism towards the general consumer market. Helm (2006) considered the consumer cynicism, same as other types of cynicism, is a learned attitude due to non-fulfilment of expectations and influenced by specific events.

\subsection{Information Processing and Consumer Behaviour}

Consumer responses in the context of advertising and marketing/brand communications are always related to information, processing and persuasion. Persuasion has become the chief tool by which important legislation gets passed, products get sold, and parents influence their children. The Elaboration Likelihood Model (ELM) (Petty \& Cacioppo, 1981) was developed to explain and organize past conflicts in persuasion literature as well as to guide new research. the ELM posits that for the sake simplicity, persuasion can be thought of as following one of two routes to persuasion: central and peripheral. The central route involves attitude changes that require much effort and thought to reach a decision. The second route, the peripheral route, involves attitude changes that occur primarily when elaboration is low, and it can entail thought processes that are quantitatively or qualitatively different from the high-elaboration central route.

\subsection{Hypothesis}

Cynicism and information processing- Kanter and Wortzel (1985) argued that cynical individuals are generally less like to believe information from any source and are especially likely to attribute advertising claims to selling motives rather than strict honesty. Obermiller and Spangenberg (1998) also suggested that cynical individuals rejected testimonial and demonstration ad appeals more than non-cynical individuals. Attribution theory may be relevant because it is concerned with how individuals assess the cause of others' behaviour. Under this rationale, cynicism is believed to result from a dispositional attribution (i.e., selling motives) for the claims of ads. In other words, cynics tend to deal with ad information simply with less cognitive efforts, via a more intuitive or heuristic route. In sum, cynicism research tends to suggest that cynics have a greater tendency to heuristic information processing, whereas non-cynics tend to more detailed processing.

H1: Cynics, will exhibit different attitude toward the ad (Aad) from non cynics. 
Mood and cynicism- Mood states have the potential to not only influence the degree of cognitive elaboration, but also the valence of the material retrieved from memory that can be used as an input for information process or making judgments. As happy mood states result in less effortful processing and cynics are more predisposed to heuristic processing, happy mood state should cause cynics to engage in a minimalist level of information processing. On the other hand, sad moods encourage more extensive mental effort.

According Forgas (1995), there are four processing strategies existing for the influence of affect: direct-access, heuristic, substantive, and motivated strategies. Among these four strategies, direct-access strategies represent the lowest form of effort minimalization, even lower than heuristic processing. There is no motivation, the judgment is uninvolved, and the target has prototypical features. For these effort mimimalizers, this represents a preferred strategy (Forgas, 1995), which means that a preexisting evaluation is used for prototypical stimuli. That is, happy cynics would be most easily influenced by the ads.

H2: Cynics, under happy-mood conditions, will exhibit most favorable attitude toward the ad (Aad).

\section{DATA AND METHODOLOGY}

\subsection{Subjects and Product Context}

Sixty-four undergraduate and postgraduate management students participated in the study (34 females, 30 males). Subjects participated in groups, with groups randomly assigned to treatment conditions. Dog foods and service was chosen as the product category based on three criteria: Subject knowledge, Equal Gender Relevance (Gainer, 1993), and commercially successful. Two most effective TV ads were selected by the pretest.

\subsection{Procedure}

Subjects were told that the purpose of the study was to find out how people evaluate television programs and ads. Next, subjects were asked to answer the first part of the questionnaire, the 23-items Cynicism scale from Minnesota Multiphasic Personality Inventory 2 (MMPI-2). Then they are asked to seat themselves in a comfortable manner to view the television. The mood induction television program was then played. When it was over, subjects completed a scale that measured post mood-induction mood scores (1=Sad, 7=Happy). Such a global measure of mood is consistent with past research. The ads were then played, after which subjects completed the remainder of the questionnaire at their own pace.

Measures- Attitude toward the ad (Aad) was rated on two 7-point items anchored by: "bad"-"good," and "dislike"-“like,". One 7-point items measured attitude toward the brand (Ab) anchored by: "dislike"-"like." The reliability of these scales was sufficiently high (Cronbach's alpha=0.79 and 0.90 for Aad and Ab, respectively), which is consistent with past research that has used these items (e.g., Yi, 1990, 1993). The questionnaire included two manipulation checks. First, a mood-manipulation check asked subjects to rate how they felt after having watched the program $(-3=\operatorname{sad},+3=$ happy). Second, a check was performed for affective tone, with subjects rating the extent to which the ad seemed happy or $\operatorname{sad}(-3=\mathrm{sad},+3=$ happy). A measure of consumer involvement with the ad was included as a covariate. The present study utilized Mittal's (1995) five-item adaptation of Zaichowsky's (1985) Personal Involvement Inventory (PII).

\section{FINDINGS AND DISCUSSIONS}

\subsection{Hypothesis Testing}

$\mathrm{H} 1$ posits that cynics will exhibit different attitude toward the ad (Aad) from non cynics, whereas $\mathrm{H} 2$ predicts that happy cynics will exhibit most favorable attitude toward the ad (Aad).

To ascertain whether cynicism interacted with mood state, a 2 (mood: happy, sad) X 2 (cynicism: cynical, non-cynical) MANOVA was performed on Aad and Ab. This analysis revealed a main effect for cynicism $(F=4.028, p=.05)$ for Aad as displayed in Table 1. Overall, cynical subjects rated the ads more favourably than the non cynical subjects (Mean cynics $=1.50$ vs. Mean of non cynics $=1.15)$. Importantly, the interaction for mood and cynicism was nearly significant for Aad $(F=3.684, p=.065)$.

Table 1: Analysis of Variance Results for Attitude toward the Ad. 


\begin{tabular}{lccc}
\hline Source of Variation & Mean Square & $\begin{array}{c}\text { Degrees of } \\
\text { Freedom }\end{array}$ & F Ratio \\
\hline Mood (A) & .741 & .827 & .371 \\
Cynicism(B) & 3.609 & 4.028 & $.054^{*}$ \\
A X B & 3.330 & 3.684 & $.065^{*}$ \\
\hline * $_{\text {p.10. }}$ & & &
\end{tabular}

As displayed in Figure 1 and consistent with H2, happy cynics will exhibit most favorable attitude toward the ad (Aad). In other words, happy cynics are most easily influenced by the ads. However, there is no same simple main effect nor the interaction between cynicism and mood on the dependent variable of attitude toward the brand (Ab).

Figure 1: Plot of the Interaction of Mood and Cynicism on Attitude toward Ad.

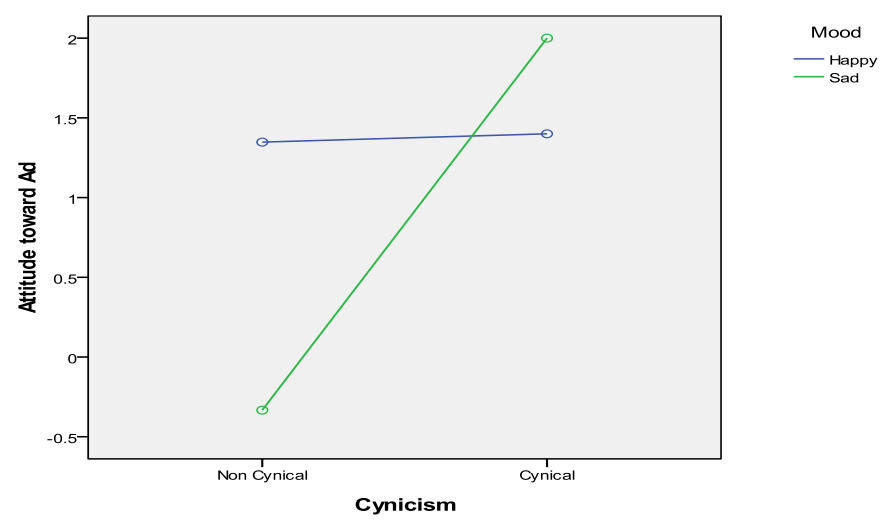

\section{CONCLUSION}

The objective of this study was to assess whether cynicism interacted with mood effects, specifically, to examine the interaction of cynicism, and television-program-induced mood states in the context of Aad and Ab. The findings yielded support for the hypotheses that cynics would exhibit more favourable Aad evaluations of ads, whereas non cynics would show no distinction for ad evaluations of Aad. Findings also supported the mood and cynicism processing differences that were posited to underlie the Aad findings.

Furthermore, although the present study provides support for the hypothesis for cynicism-mood effects, it would be of interest to examine the effect on broader product categories. It would also be of interest to see what sort of processing was occurring in different involvement level products ad processing. For example, Grunert (1996) suggested two kinds of cognitive processing: automatic processing and strategic processing. Which process is more applicable to cynicism-mood effects? A significant stream of consumer research has examined the effect of arousal in a persuasive communication context. In the context of the present study, arousal may have influenced the manner of processing used by subjects. It would be interesting to consider more deeply about the relationship and interaction between these factors in the future studies

\section{REFERENCES}


Agger, R., Goldstein, M., \& Pearl, S. (1961). Political Cynicism: Measurement and Meaning. Journal of Politics, 23, 477-506.

ANDERSSON, L., \& BATEMAN, T. (1997). Cynicism in the workplace: some causes and effects. JOURNAL OF ORGANIZATIONAL BEHAVIOR, 18, 449469.

Bagozzi, R., Gopinath, M., \& Nyer, P. (1999). The role of emotions in marketing. Journal of the Academy of Marketing Science, 27(2), $184-206$.

Barone, D., Hersen, M., \& Van Hasselt, V. (2004). Advanced Personality: Springer.

Bateman, T., Sakano, T., \& Fujita, M. (1992). Roger, Me, and My Attitude: Film Propaganda and Cynicism Toward Corporate Leadership. Journal of Applied Psychology, 77, 768-768.

De Vreese, C. H. (2005). The Spiral of Cynicism Reconsidered. European Journal of Communication, 20(3), 283.

De Vreese, C. H. (2005). News framing: Theory and typology. Information design journal+ document design, 13(1), 51-62.

Forgas, J. (1995). Mood and judgment: the affect infusion model (AIM). Psychol Bull, 117(1), 39-66.

Gainer, B. (1993). An empirical investigation of the role of involvement with a gendered product. Psychology \& Marketing, $10(4), 265-283$.

Grunert, K. G. (1996). Automatic and strategic processes in advertising effects. The Journal of Marketing, 88-101.

Guastello, S., Rieke, M., Guastello, D., \& Billings, S. (1992). A study of cynicism, personality, and work values. The Journal of psychology, 126(1), 37-48.

Helm, A. E. (2006). Cynical consumers: dangerous enemies, loyal friends. Citeseer.

Kaid, L. (2007). The Effects of Political Advertising on Young Voters. American Behavioral Scientist, $50(9), 1137$.

Kanter, D., \& Mirvis, P. (1989). The Cynical Americans: Living and Working in an Age of Discontent and Disillusion: Jossey-Bass.

Kanter, D., \& Wortzel, L. (1985). Cynicism and alienation as marketing considerations: Some new ways to approach the female consumer. Journal of Consumer Marketing, 2(1), 5-15.

Lidstone, J. (2005). Blazer to the Rescue. Australian Journal of Emergency Management.

Maheswaran, D., \& Meyers-Levy, J. (1990). The influence of message framing and issue involvement. Journal of Marketing Research, 27(3), 361367.

Mangleburg, T., \& Bristol, T. (1998). Socializing and Adolescents' Skepticism toward Advertising. Journal of Advertising, $27(3), 11-12$.

Meyers-Levy, J., \& Maheswaran, D. (1991). Exploring Differences in Males' and Females' Processing Strategies. Journal of Consumer Research, $18(1), 63$.

Mittal, B. (2006). A comparative analysis of four scales of consumer involvement. Psychology and Marketing, 12(7), 663-682.

Naus, F., van Iterson, A., \& Roe, R. (2007). Organizational cynicism: Extending the exit, voice, loyalty, and neglect model of employees' responses to adverse conditions in the workplace. Human Relations, 60(5), 683.

Obermiller, C., \& Spangenberg, E. (1998). Development of a Scale to Measure Consumer Skepticism Toward Advertising. Journal of Consumer Psychology, 7(2), 159-186.

Obermiller, C., Spangenberg, E., \& MacLachlan, D. (2005). AD SKEPTICISM: The Consequences of Disbelief. Journal of Advertising, 34(3), 7-17.

Petty, R., \& Cacioppo, J. (1984). The effects of involvement on argument quality and quantity: Central and peripheral routes to persuasion. Journal of Personality and Social Psychology, 46, 69?61.

Pinkleton, B., Um, N., \& Austin, E. (2002). An exploration of the effects of negative political advertising on political decision making. Journal of Advertising, 31(1), 13-25.

Schenck-Hamlin, W., Procter, D., \& Rumsey, D. (2000). The influence of negative advertising frames on political cynicism and politician accountability. Human Communication Research, 26(1), 53-74.

Stanley, D., Meyer, J., \& Topolnytsky, L. (2005). Employee Cynicism and Resistance to Organizational Change. Journal of Business and Psychology, $19(4), 429-459$.

Tan, S. (2007). Antecedents and Consequences of Skepticism toward Health Claims: An Empirical Investigation of Singaporean Consumers. Journal of Marketing Communications, 13(1), 59-82. 
Turner, J., \& Valentine, S. (2001). Cynicism as a Fundamental Dimension of Moral Decision-Making: A Scale Development. Journal of Business Ethics, 34(2), 123-136.

Wanous, J., Reichers, A., \& Austin, J. (2000). Cynicism about Organizational Change: Measurement, Antecedents, and Correlates. Group \& Organization Management, 25(2), 132.

Yi, Y. (1993). The determinants of consumer satisfaction: the moderating role of ambiguity. NA-Advances in Consumer Research Volume 20.

Yi, Y., \& Zeithaml, V. A. (1990). A critical review of consumer satisfaction. Review of marketing, 4(1), 68-123.

Yoon, K., Pinkleton, B., \& Ko, W. (2005). Effects of Negative Political Advertising on Voting Intention: An Exploration of the Roles of Involvement and Source Credibility in the Development of Voter Cynicism. Journal of Marketing Communications, 11(2), $95-112$.

Zaichowsky, J. (1985). Measuring the Involvement Construct in Marketing. Journal of Consumer Research, 12(3), 341-352. 